\title{
Eksistensi Laboratorium Pendidikan Agama Islam (PAI) dalam Materi Perawatan Jenazah
}

\author{
Suparwoto Sapto Wahono ${ }^{*}$, Dinik Nurul Fuadah ${ }^{2}$ \\ ${ }^{1}$ Institut Agama Islam Negeri Jember \\ 2 Institut Agama Islam Negeri Jember
}

Keywords:

Laboratorium Pendidikan

Agama Islam, Perawatan Jenazah

*Correspondence Address: nuruldini668@gmail.com wahsapto@gmail.com

\begin{abstract}
The process of treating corpses requires skill, therefore repeated experience is needed. The existence of a laboratory is very important, both used in the introduction of material in theory and practice. In practice, the care of corpse requires learning resources, teaching aids and so on to support the implementation of corpse care practices. This study aimed to determine the existence of the PAI laboratory seen from the conditions, management and use of the PAI laboratory in the practice of corpse care materials. The method in this study used a descriptive qualitative approach. The results showed that the conditions of the PAI laboratory met the comfort requirements of the PAI laboratory. The PAI Laboratory management has an organizational structure and is in charge of the PAI laboratory inventory. The use of PAI laboratory in the practice of caring for corpses was carried out in semester 4 (four), namely class 2 even semester. In the implementation of the practice of caring for the corpse, it began with "breafing" as a provision of practice, the core activities of caring for the corpse were bathing, shrouding, praying and burying the corpse. As well as closing activities, namely giving wisdom from the care of corpses carried out at the PAI Laboratory.
\end{abstract}

\begin{abstract}
Abstrak: Proses merawat mayat membutuhkan keterampilan, oleh karena itu diperlukan pengalaman yang berulang-ulang. Keberadaan laboratorium sangat penting, baik digunakan dalam pengenalan materi secara teori maupun praktek. Dalam praktiknya, perawatan jenazah membutuhkan sumber belajar, alat peraga dan sebagainya untuk mendukung pelaksanaan praktik perawatan jenazah. Penelitian ini bertujuan untuk mengetahui kontribusi dan eksistensi laboratorium PAI dilihat dari kondisi, pengelolaan dan pemanfaatan laboratorium PAI dalam praktik materi perawatan jenazah. Metode dalam penelitian ini menggunakan pendekatan kualitatif deskriptif. Hasil penelitian menunjukkan bahwa kondisi laboratorium PAI memenuhi syarat kenyamanan laboratorium PAI. Pengelola Laboratorium PAI memiliki struktur organisasi dan membawahi inventaris laboratorium PAI. Pemanfaatan laboratorium PAI dalam praktik perawatan jenazah dilakukan pada semester 4 (empat) yaitu kelas 2 semester genap. Dalam pelaksanaan praktik merawat jenazah diawali dengan "breafing" sebagai bekal praktik, kegiatan inti merawat jenazah adalah memandikan, menyelubungi, berdoa dan menguburkan jenazah. Serta kegiatan penutup yaitu pemberian hikmah dari perawatan jenazah yang dilakukan di Laboratorium PAI.
\end{abstract}

\section{PENDAHULUAN}

Pendidikan keagamaan memberi pengaruh bagi pembentukan jiwa keagamaan pada peserta didik dan tergantung dari kemampuan para pendidik untuk menimbulkan 3 proses, yakni guru agama harus mampu merencanakan materi, metode serta alat bantu yang memungkinkan peserta didik memberikan perhatian, pemahaman kepada peserta didik tentang materi pendidikan yang diberikannya dan Penerimaan peserta didik terhadap materi pendidikan 
agama yang diberikan. Penerimaan ini sangat tergantung pada hubungan antara materi dengan kebutuhan dan nilai bagi kehidupan anak didik. ${ }^{1}$ Pendidikan yang merupakan proses budaya dalam rangka meningkatkan harkat dan martabat manusia sepanjang hayat (long life education), sehingga diharapkan pendidikan selalu berkembang dengan beberapa karakter pendidikan yang selaras seiring perubahan zaman. Long life education merupakan asas pendidikan yang cocok bagi manusia yang hidup dalam dunia transformasi. Setiap manusia dituntut untuk menyesuaikan dirinya secara terus menerus dengan situasi baru. ${ }^{2}$

Tujuan belajar dalam perspektif teori humanistik adalah untuk memanusiakan manusia. Proses belajar dianggap berhasil jika siswa telah memahami lingkungannya dan dirinya sendiri ${ }^{3}$. Dalam hal ini manusia dituntut untuk berperilaku dan memperlakukan yang baik serta saling memberi manfaat pada sesama manusia.

Pendidikan tidak bisa berdiri sendiri namun membutuhkan beberapa komponen yang dapat mendukungnya, yakni lingkungan, pengajar (guru), peserta didik, serta dana, sarpras, kurikulum dan lain sebagainya guna menyiapkan manusia yang utuh. Lingkungan pendidikan yang lebih trend dikenal dengan lembaga sekolah, urgensinya membantu lingkungan keluarga. Maka

1Zulaichah Ahmad, Psikologi Agama, (Jember: STAIN Jember Press), h. 126-127.

${ }^{2}$ Abd. Muis Thabrani, Pengantar dan DimensiDimensi Pendidikan, (Jember : STAIN Jember Press,2013),75.

3 Hamidulloh Ibda. 2020. Kontekstualisasi humanime religius perspektif Muhammed Arkoun dalam dalam pendidikan Islam dasar. At-Tajdid: Jurnal Ilmu Tarbiyah, Vol. 9 No. 1, Januari 2020, hal. 38 sekolah bertugas untuk mendidik, mengajar serta memperbaiki dan memperhalus tingkah laku peserta didik.

Pendidikan keagamaan yang berkembang saat ini juga disertai dengan usaha demi terciptanya pendidikan keagamaan yang sesuai dengan materi, baik secara teori dan praktik. Keberadaan laboratorium sangat penting terutama dalam praktik untuk mendukung teori sehingga penggunaan laboratorium menjadi efektif bagi pembelajaran PAI. Menurut Haidar, pendidikan agama Islam membutuhkan sarana dan fasilitas. Bila ada laboratorium IPA, laboratorium Biologi, laboratorium bahasa, maka sekolah juga membutuhkan laboratorium agama disamping adanya masjid. ${ }^{4}$

Keberadaan laboratorium PAI dapat menghasilkan pengalaman belajar yang dibutuhkan oleh siswasiswi untuk dapat menguasai materi pelajaran. Materi perawatan jenazah merupakan salah satu materi yang tidak hanya membutuhkan teori tetapi juga praktik. Untuk mempermudah praktik maka perlu dilengkapi dengan media. Wahono (2019: 594) menyatakan, "the purpose of media is to facilitate communication and learning" bahwa tujuan media adalah untuk mempermudah komunikasi dan pembelajaran ${ }^{5}$. Dengan pengalaman melakukan praktik perawatan jenazah yang didukung oleh laboratorium dan dan didukung oleh alat dan media akan

4 Haidar Putra Daulay dan Nurgayapasa. Pendidikan Islam dalam mencerdaskan bangsa, (Jakarta: Rineka Cipta, 2012), 39

5 Suparwoto Sapto Wahono, Ulfa Khodijatul Qodriah. 2019. Improving Students Writing Skill Using English Movie with Subtitle. International Journal of Scientific and Research Publications. Vol. 9 (12) December. 2019: 593599 
meningkatkan interaksi siswa-siswi sebagai dalam memahami materi dan praktik. Praktik perawatan jenazah dilakukan secara berurutan mulai dari memandikan, mengkafani, menyolati dan menguburkan jenazah sesuai dengan tata cara.

Kondisi, pengelolaan dan penggunaan laboratorium PAI, setidaknya sesuai dengan tujuan diadakannya laboratorium Pendidikan Tujuan laboratorium Pendidikan Agama Islam, Sebagaimana dalam Permenpan No.3 Tahun 2010, maka tujuan diadakannya laboratorium yakni; (1) sebagai ruangan atau tempat penunjang akademik dalam bidang keagamaan, (2) sebagai tempat menguji peserta didik di bidang keagamaan baik materi, sikap beribadah dan kebudayaan keagamaan, (3) sebagai kalibrasi atau tempat melakukan kegiatan yang membentuk hubungan antara nilai yang ditunjukkan oleh instrumen ukur atau sistem pengukuran, yang mengukur kebenaran konvensional dari nilai dan norma, (4)Tempat peraga keilmuan tertentu.

Maka dari itu keberadaan laboratorium sangat penting dalam mengembangkan materi pelajaran pendidikan agama Islam. Duddin (2018) menyatakan bahwa tercapainya tingkat standar laboratorium PAI SMAN 3 Bandung memberikan manfaat yang memadai. ${ }^{6}$ Lebih lanjut Elmidasyam (2018) menyatakan bahwa sebagai sumber belajar, laboratorium agama SMP Negeri 1 Payakumbuh efektif dan penggunaan alat praktikum PAI sebagai sumber belajar dapat meningkatkan aktivitas belajar peserta

6 Achmad Duddin, Studi Kasus Laboratorium Pendidikan Agama Islam di SMAN 3 Bandung, didik di SMP Negeri 1 Payakumbuh. ${ }^{7}$ Hal tersebut juga didukung oleh Hayadin (2015) bahwa dalam rangka mendukung pembelajaran PAI dalam praktek penyelenggaraan perpustakaan PAI di Sekolah umum, perpustakaan PAI yang berdiri sendiri secara khusus bergabung dengan perpustakaan sekolah, bergabung dengan masjid, dan bergabung dengan laboratorium sekolah. ${ }^{8}$ Hal ini menunjukkan pentingnya laboratorium PAI di sekolah. Standar laboratorium, efektifitas laboratorium dan ruangan menjadi salah satu tempat melakukan kajian keagamaan. Disamping itu keberadaan laboratorium baik dari sisi kondisi, pengelolaan dan penggunaan perlu diperhatikan.

Kondisi laboratorium perlu dijaga dengan baik karena menjadi asset dalam pembelajaran. Laboratorium sebagai tempat pengembangan belajar akan lebih membuat siswa-siswi mampu menganalisis kajian-kajian keilmuan mengenai keagamaan secara mendalam. Kajian materi pembelajaran pendidikan agama Islam khususnya materi perawatan jenazah yang diberikan kepada peserta didik dengan menggunakan laboratorium sebagai penunjang praktik akan lebih mudah dipahami.

Tujuan penelitian ini adalah untuk mendeskripsikan kondisi, pengelolaan, dan penggunaan

\footnotetext{
7 Elmidasyam, Efektifitas Penggunaan Laboratorium PAI sebagai Sumber Belajar dalam Meningkatkan Aktivitas Belajar Peserta didik di SMP Negeri 1 Payakumbuh, Tesis, Fakultas Tarbiyah UIN Imam Bonjol, Padang, 2018.

8 Hayadin, Eksistensi Perpustakaan Pendidikan Agama Islam di Sekolah Umum, survei Puslitbang Pendidikan Agama dan Keagamaan. Badan Litbang \& Diklat Kementrian Agama RI. ,Jakarta Pusat, 2015.
} 
laboratorium PAI pada materi perawatan jenazah di SMKN 5 Jember.

\section{KAJIAN TEORI}

\section{Laboratorium}

Laboratorium Pendidikan Agama Islam, mempunyai beberapa pengertian, yaitu menurut Haidar, Laboratorium pendidikan agama islam merupakan ruangan khusus yang di tata dengan baik, dengan nuansa religius, misalnya seni musik, sajak, puisi religius dan vidio yang mengisahkan nuansa keberagamaan. Peserta didik secara bergiliran pada hari-hari yang ditentuka mengikuti pembelajaran ditempat tersebut. Laboratorium PAI dapat dipahami sebagai suatu bagunan yang didalamnya di lengkapi dengan peralatan dan bahan-bahan berdasarkan metode keilmuan tertentu untuk melakukan percobaan ilmiah, penelitian, praktik pembelajaran, kegiatan pengujian, dan produksi bahan tertentu dalam hal kaitannya dengan persoalan agama Islam ${ }^{9}$.

\section{Urgensi laboratorium PAI}

Laboratorium PAI di sekolah harusnya dikelola dengan baik agar dapat mempermudah pembelajaran PAI yang dapat menghasilkan pengalaman belajar yang dibutuhkan peserta didik baik dalam bentuk pembiasaan sikap dan lain sebagainya. Laboratorium adalah suatu bentuk mengajar yang menghadapkan peserta didik dengan benda-benda dan peristiwa-peristiwa

\footnotetext{
9 Ratna Sundari. Evaluasi Pemanfaatan Laboratorium Pembelajaran Biologi Di Madrasah Aliyah

Negeri Sekabupaten Sleman, dalam http://jurnal.uny.ac.id/index.php.jpep/article/ download/1427/1215, diakses 2020-12-11.
}

\section{Tujuan Laboratorium PAI}

Dalam Permenpan No. 3 Tahun

2010 Laboratorium adalah unit penunjang akademik pada lembaga pendidikan, berupa ruangan tertutup atau terbuka, bersifat permanen atau bergerak, yang dikelola secara sistematis untuk pengujian, kalibrasi, dan atau produksi dalam skala terbatas, dengan menggunakan peralatan dan bahan berdasarkan metode keilmuan tertentu, dalam rangka pelaksanaan pendidikan, penelitian, dan atau pengabdian kepada masyarakat ${ }^{10}$.

Tujuan

laboratorium Pendidikan Agama Islam, Sebagaimana dalam Permenpan No.3 Tahun 2010, maka tujuan diadakannya laboratorium yakni;

1) Sebagai ruangan atau tempat penunjang akademik dalam bidang keagamaan.

2) Sebagai tempat menguji peserta didik di bidang keagamaan baik materi, sikap beribadah dan kebudayaan keagamaan.

3) Sebagai kalibrasi atau tempat melakukan kegiatan yang membentuk hubungan antara nilai yang ditunjukkan oleh instrumen ukur atau sistem pengukuran, yang mengukur kebenaran konvensional dari nilai dan norma.

4) Tempat peraga keilmuan tertentu. Seperti halnya pembelajaran yang membutuhkan praktik di dalamnya seperti perawatan jenazah, mulai dari memandikan jenazah, mengkafani jenazah, mensolatkan dan mengubur jenazah.

\section{Fungsi Laboratorium PAI}

Keberadaan laboratorium dapat menjadi satu hal yang sangat penting

\footnotetext{
10 Permenpan No. 3 Tahun 2010 tentang Jabatan Fungsional Pranata Laboratorium dan Angka Kreditnya.
} 
dalam menunjang peningkatan mutu, maka dari itu fungsi laboratorium dalam hal ini diantaranya:

1) Sebagai tempat untuk belajar mengembangkan diri dengan melatih diri dengan melatih keterampilan spiritual, intelektual, sicial dan pendewasaan sikap, pemahaman komprehensif terhadap ajaran agama Islam dan penanaman nilai-nilai akhlak mulia

2) Sebagai tempat sharing keilmuan, diskusi, penelitian dan pemberi solusi problematika umat Islam.

\section{Perawatan Jenazah}

Adapun syarat-syarat orang yang diperbolehkan memandikan jenazah sebagaimana dikutip Kamil (2008) dalam Pulungan dkk. (2020) ${ }^{11}$ adalah: a) Islam, berakal dan baligh, b)Niat memandikan jenazah, c) Bisa dipercaya (merahasiakan aib dan cacat tubuh jenazah), d) Mengetahui tata cara memandikan jenazah. Adapun orang yang utama untuk memandikan jenazah orang tertentu berbeda antara jenazah laki-laki dan perempuan yakni; 1) Bagi jenazah laki-laki, orang yang utama untuk memandikan jenazah laki-laki urutannya adalah: a. Orang yang mendapat wasiat untuk memandikan, b. Bapak, kakek, kerabat dekat dan mahrim laki-laki dan istri dari yangmeninggal. 2) Bagi jenazah wanita, orang yang lebih utama untuk memandikan jenazah perempuan urutannya adalah: a. Ibu, nenek, kerabat dekat dari pihak perempuan. b. Suami dari jenazah.

11 Sahmiar Pulungan. 2020. Peningkatan Keterampilan Pengurusan Jenazah di MTs Ulumul Quran Medan. Qalamuna -Jurnal Pendidikan, Sosial, dan Agama | Vol. 12 No. 1 (2020)25-35

\section{Menyolati Jenazah}

Shalat jenazah adalah shalat yang dilakukan atas jenazah secara langsung. Bila jenazah itu tidak berada di tempat di sebut shalat ghaib.Shalat jenazaah dilakukan setelah jenazah selesai dimandikan dan dikafani. Shalat jenazah terdiri dari empat kali takbir, setelah takbir pertama dibaca surat Al-fatihah, setelah takbir kedua dibaca shalawat atas nabi dan setelah takbir ketiga dan ke empat dibaca do'a untuk jenazah untuk umat islam semuanya (Syefuddin dalam Mubarok dan Arif, 2020: 257-25812. Shalat jenazah memiliki syarat-syarat seperti syarat-syarat shalat yang lain. Diantarnya adalah suci badan, suci dari hadats kecil dan hadats besar, menghadap kiblat, dan menutup aurat. Akan tetapimengenai waktu pelaksanaan shalat, terdapat perbedaan antara shalat jenazah dan shalat lainnya. Shalat jenazah dilakukan kapan saja ketika jenazah telah siap untuk dishalatkan (Sayyid Sabiq dalam Mubarok dan Arif, 2020: 257-258) ${ }^{13}$. Berikut ini adalah tata cara mensholatkan jenazah:

1. Jumlah takbir 4 kali.

2. Setelah takbiratul ihrampertama, membaca alFatihah.

3. Mengangkat kedua tangan setiap kali takbir.

4. Setelah takbir ke-2 membaca sholawat kepada Nabi, diutamakan sholawat yang diajarkan Nabi dalam tahiyyat sholat (Ibrahimiyyah).

12 Khoirul Anam Mubarok dan Miftahul Arif. 2020. Pendampingan Pelatihan Tajhizul Mayit Sebagai Wujud Pengimplementasian Ilmu Agama Pada Mahasiswa Tahun Pertama di Asrama Mahasiswa Putra IAI Faqih Asy'ari Kediri JPMD: Jurnal Pengabdian kepada Masyarakat Desa. Vol. 1, Number 1, 2020.

13 Ibid. 
5. Setelah takbir ke-3 membaca doa untuk kaum muslimin secara umum dan doa untuk mayit secara khusus sebagaimana bacaan yang diajarkan Nabi.

6. Setelah takbir ke-4 dan seterusnya boleh membaca doa untuk mayit lagi.

7. Mengucapkan salam dua kali (menoleh ke kanan dan kiri)dengan bacaan lengkap.

8. Jika jenazahnya adalah laki-laki, Imam berdiri sejajar kepala. Jika jenazahnya perempuan, Imam berdiri di tengah jenazah.

\section{METODE}

Penelitian ini menggunakan pendekatan deskriptif kualitatif. Adapun teknik pengumpulan data menggunakan observasi, wawancara, dan dokumen. Teknik pengumpulan data tersebut digunakan untuk menggali data tentang kondisi, pengelolaan, dan dan penggunaan laboratorium pendidikan Agama Islam pada materi perawatan jenazah.

\section{HASIL DAN DISKUSI \\ Kondisi Laboratorium PAI}

Sarana pembelajaran dalam laboratorium PAI di SMKN 5 Jember yang terkait dengan materi perawatan jenazah terdiri dari meja tempat memandikan jenazah, lemari, rak, alat peraga, torso jenazah, kain kafan, alat memandikan jenazah, papan tulis alat tulis, kursi. Sarana tersebut dalam kondisi yang memadai untuk digunakan sebagai praktik perawatan jenazah.

\section{Pengelolaan Laboratorium PAI}

Laboratorium PAI di SMK 5 Jember dikelola oleh guru-guru PAI dengan azas kebersamaan yang didukung oleh kepala sekolah sebagai penanggung jawab. Adanya struktur pengelolaan laboratorium PAI di sekolah menjadi bukti dan komitmen keseriusan sekolah dalam menangani laboratorium. Laboratorium PAI juga dilengkapi dengan tata tertib untuk siswa agar mereka dapat menjaga kebersihan, ketertiban dan keamanan dalam menggunakan laboratorium tersebut.

\section{Penggunaan Laboratorium PAI}

Penggunaan laboratorium PAI pada materi perawatan jenazah dibagi atas tiga yakni:

1. Kegiatan pembuka. Kegiatan pembuka dalam pelaksanaan praktik perawatan jenazah di lakukan dengan persiapan yakni memberikan "breafing" berupa penjelasan singkat tata cara perawatan jenazah atau video perawatan jenazah sebagai rangsangan dan bekal saat praktik perawatan jenazah yang dilakukan.

2. Dalam pelaksanaannya, kegiatan ini dibagi antara siswa laki-laki dan siswi perempuan, dan kedua pembagian tersebut terbagi lagi 2 kelompok, sehingga menjadi 4 kelompok yang sesuai dengan jumlah sub materi perawatan jenazah yakni memandikan, mengkafani, menyolati, dan terakhir adalah menguburkan jenazah.

1) Memandikan jenazah dilakukan secara berurutan dengan basuhan-basuhan

menggunakan gayung. Pada praktik perawatan jenazah, siswa masih canggung melakukan karena materi ini adalah materi yang baru mereka ketahui. 
Proses memandikan jenazah

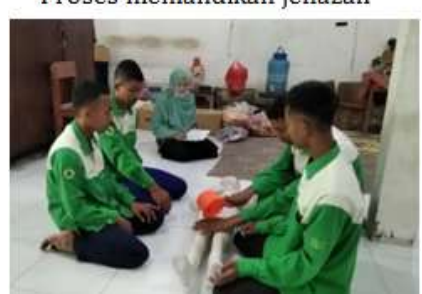

2) Mengkafani jenazah dilakukan dengan peraga torzo laki-laki, sesuai dengan siswa-siswa yang praktik. Sehingga mereka mengerti bahwa bagi laki-laki merawat jenazah untuk lakilaki, dan perempuan juga merawat jenazah perempuan. Pada proses mengkafani ini siswa lebih berhati-hati karena lapisan demi lapisan yang digunakan harus sesuai dengan urutan yang telah dijelaskan guru agama. Sehingga ketika mengkafani jenazah sungguhan akan lebih mudah dan tidak lupa. Seperti hal yang kecil yakni peletakan tali kafan sebagai pengikat jenazah, diletakkan terlebih dahulu dari lapiran-lapisan kain kafan pembungkus jenazah. Dalam Pelaksanaan mengkafani jenazah laki-laki menggunakan kain kafan dengan 4 lapis. Hal ini dikarenakan kain kafan yang ada ukurannya tidak sesuai dengan torzo jenazah. Sehingga 1 lapis luas, dan 2 lapis diposisikan berdampingan sehingga dapat menutupi jenazah, dan lapis dalam atau lapis ketiga adalah baju untuk menutupi aurat jenazah.

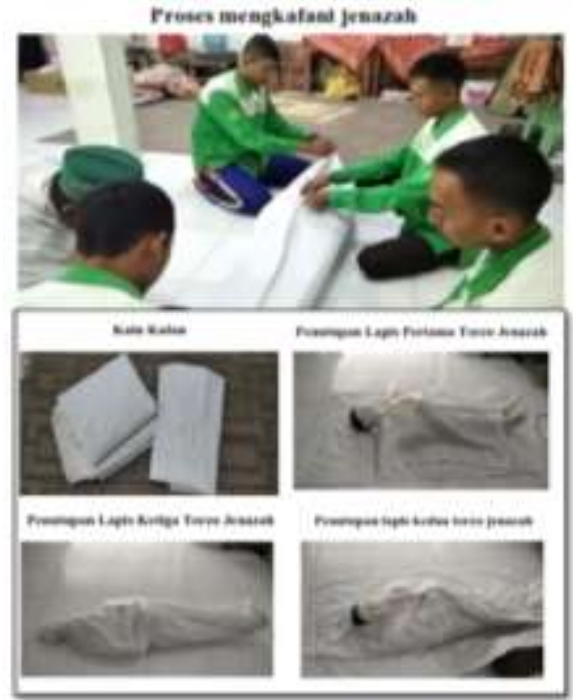

3) Dalam pelaksanaan sholat jenazah, guru agama memberi contoh menjadi imam. Setelah itu siswa diberi kesempatan menjadi imam sholat jenazah. Dengan cara tersebut siswa dapat memahami dan mempraktikkan materi dengan baik.

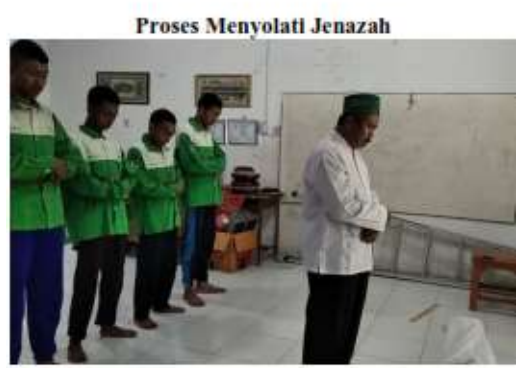

Doa Kebaikan untuk Jenazah

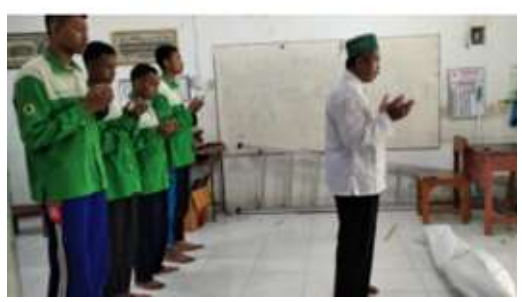

4) Proses penguburan jenazah tidak dilakukan dengan praktik. Melainkan di jelaskan dengan teori karena fasilitas tempat penguburan jenazah (liang lahat) belum ada dan tidak disetujui karena memerlukan tempat khusus dan biaya besar. 
Dalam materi perawatan jenazah juga diberikan beberapa tambahan-tambahan seperti sunnah dalam memberikan parfum dan lainnya tergantung pada adat dalam lingkungan masing-masing siswa, dan disertai dengan penjelasan lanjutan pada proses perawatan jenazah bersama siswasiswi SMKN 5 Jember.

3. Penutup, Dalam penutup materi pelaksanaan jenazah berisikan renungan mengenai hikmah kematian, dan evaluasi dari praktik yang telah dilaksanakan.

\section{KESIMPULAN}

Hasil penelitian ini dilihat dari kondisi dari sisi lokasi, luas, fasilitas laboratorium dalam materi perawatan jenazah memenuhi persyaratan kenyamanan laboratorium Pendidikan agama Islam. Pada pengelolaannya Laboratorium PAI terdapat struktur organisasi serta tanggung jawab inventaris dan tata tertib. Adapun penggunaan laboratorium dalam materi praktik perawatan jenazah diantaranya 1) kegiatan pembuka yang dibuka dengan "breafing"sebagai bekal praktik, 2) kegiatan inti dilakukan secarav berurutan dari memandikan, mengkafani dan menyolati oleh siswa dan 3) Penutup dalam pelaksanaannya diberikan hikmah dibalik praktik perawatan jenazah yang dilakukan.

Dengan adanya laboratoriun dan manfaat keberadaan laboratorium PAI, maka diharapkan lembaga pendidikan formal yang mengajarkan materi perawatan jenazah sebagai salah satu upaya untuk meningkatkan dan mengembangkan ilmu pengetahuan umum serta pendidikan keagamaan secara khusus serta mengembangkan kreativitas guru sebagai pendidik dalam pembelajaran sesuai dengan teori dan materi yang ada. Penelitian ini dapat menjadi salah satu kontribusi pemikiran untuk menunjukkan eksistensi aktifitas akademika yang ingin mengembangkan ilmu pengetahuan yang berhubungan dengan eksistensi laboratorium PAI dalam Materi Perawatan Jenazah.

\section{REFERENSI}

Ahmad. Zulaichah: Psikologi Agama. Jember: STAIN Jember Press.

Astuti. Reni: Manajemen Laboratorium yang Cerdas, Cermat, dan Selamat. Sukabumi: CV Jejak. 2020

Daulay. Haidar Putra, Nurgayapasa: Pendidikan Islam dalam mencerdaskan bangsa.Jakarta: Rineka Cipta. 2012.

Djunaidi. M., Fauzan Almanshur: Metodologi Penelitian Kualitatif. Yogyakarta: Ar-Ruzz Media. 2016

Duddin. Achmad: Studi Kasus Laboratorium Pendidikan Agama Islam di SMAN 3 Bandung, Pusat Penelitian dan Pengembangan Kementrian Agama RI. 2018.

Elmidasyam: Efektifitas Penggunaan Laboratorium PAI sebagai Sumber Belajar dalam Meningkatkan Aktivitas Belajar Peserta didik di SMP Negeri 1 Payakumbuh, Tesis, Fakultas Tarbiyah UIN Imam Bonjol, Padang, 2018.

Hayadin: Eksistensi Perpustakaan Pendidikan Agama Islam di Sekolah Umum,survei Puslitbang Pendidikan Agama dan Keagamaan. Badan Litbang \& Diklat Kementrian Agama RI. Jakarta Pusat, 2015.

Ibda. Hamidulloh: Kontekstualisasi humanime religius perspektif Muhammed Arkoun dalam dalam pendidikan Islam dasar. AtTajdid: Jurnal Ilmu Tarbiyah, Vol. 9 No. 1, Januari 2020, hal. 38 
Ibrahim: Metodologi Penelitian

Kualitatif. Pontianak:

Perpustakaan Nasional. 2015

Mahda. Yeni: Manajemen Laboratorium

Pendidikan. Pasuruan: CV.

Penerbit Qiara Media. 2020

Mubarok. Khoirul Anam, Arif Miftahul. Pendampingan Pelatihan Tajhizul Mayit Sebagai Wujud Pengimplementasian Ilmu Agama Pada Mahasiswa Tahun Pertama di Asrama Mahasiswa Putra IAI Faqih Asy'ari Kediri JPMD: Jurnal Pengabdian kepada Masyarakat Desa. Vol. 1, Number 1, 2020. 250-266.

Permenpan: tentang Jabatan Fungsional Pranata Laboratorium dan Angka Kreditnya. No. 3 Tahun 2010

Pulungan. Sahmiar: Peningkatan Keterampilan Pengurusan Jenazah di MTs Ulumul Quran Medan. Qalamuna -Jurnal Pendidikan, Sosial, dan Agama | Vol. 12 No. 1 (2020)25-35

Sugiyono: Metode Penelitian Pendidikan. Jakarta: Kencana. 2016

Sundari. Ratna: Evaluasi Pemanfaatan Laboratorium Pembelajaran Biologi Di Madrasah Aliyah Negeri Sekabupaten Sleman, 2015. https://journal.uny.ac.id/index.p hp/jpep/article/view/1427, diakses 2020-12-11.

Thabrani. Abd. Muis: Pengantar dan Dimensi-Dimensi Pendidikan. Jember : STAIN Jember Press. 2013

Wahono. Suparwoto Sapto, Qodriah.

Ulfa Khodijatul: Improving Students Writing Skill Using English Movie with Subtitle. International Journal of Scientific and Research Publications. Vol. 9 (12) December. 2019: 593-599 